\title{
Mangrove Rehabilitation on Highly Eroded Coastal Shorelines at Samut Sakhon, Thailand
}

\author{
Matsui Naohiro, ${ }^{1}$ Songsangjinda Putth, ${ }^{2}$ and Morimune Keiyo ${ }^{3}$ \\ ${ }^{1}$ Department of Environment, Kanso Technos Co., Ltd., Osaka 541-0052, Japan \\ ${ }^{2}$ Fishery Department, Trang Coastal Aquaculture Station, Trang 92150, Thailand \\ ${ }^{3}$ Power Engineering ReD Center, The Kansai Electric Power Co., Inc., Kyoto 609-0237, Japan \\ Correspondence should be addressed to Matsui Naohiro, matui_naohiro@kanso.co.jp
}

Received 8 July 2011; Revised 20 September 2011; Accepted 20 October 2011

Academic Editor: L. M. Chu

Copyright ( $\odot 2012$ Matsui Naohiro et al. This is an open access article distributed under the Creative Commons Attribution License, which permits unrestricted use, distribution, and reproduction in any medium, provided the original work is properly cited.

\begin{abstract}
The study site is currently retreating at a rate of $20 \mathrm{~m} \mathrm{y}^{-1}$ due to severe coastal erosion and found to be highly polluted as revealed from the water, sediment and biological analysis. In an attempt to prevent coastal erosion, 14,000 Rhizophora mucronata (RM) trees were planted across a heavily eroded shoreline at Samut Sakhon, Thailand. The survival rate of RM was high at the landward area and decreased at the offshore area. The most landward plot showed the highest survival rate when measured 4 years after planting $(63.5 \%)$, while only $26.7 \%$ of trees survived at the most offshore plot. NPK and coconut fiber were shown to be significantly effective to enhance initial tree growths in heavily eroded area.
\end{abstract}

\section{Introduction}

Coastal erosion is one of the most severe environmental problems currently affecting Thailand, and the Thai Government has designated this problem as a high priority among national environmental problems to be solved urgently. Coastal erosion is accelerated with the destruction of mangrove forests that normally provide protection from erosion. Thousands of abandoned shrimp ponds in coastal areas of Thailand represent decades of mangrove destruction. It is therefore necessary to rehabilitate these sites in the interests of coastal protection.

Samut Sakhon is located approximately $50 \mathrm{~km}$ from Bangkok. Because of its proximity to the capital, coastal development began at this site in the 1970s. As there were no legislative restrictions on coastal development at that time, poorly planned coastal developments were carried out up to the very edge of the coast; this practice is now prohibited by law. Inland damming at the upper reaches also was actively conducted. Sediment is transported from the upper reach to lower lands and accumulates there. Reduced flux of sediment due to hydraulic dam had severe impacts on changes of
Samut Sakhon coastlines. Under the influence of direct wave/ wind attack and without protection from mangrove forests, unprecedented coastal erosion has occurred in this region.

Mangrove plantations in vulnerable areas could be beneficial for long-term coastal protection both to continuous erosion and to severe hazard such as tsunami. The presence of mangrove as well as continuous riverine sediment flux is essential to maintain coastal stability. Over the years, a number of mangrove planting projects have been carried out to restore degraded mangrove forests [1-3], some of which aimed at protecting shoreline against storm and cyclone damage. Rehabilitation must be urgently implemented to prevent further coastal erosion; however, planting mangroves within eroded areas is far more difficult than planting at other sites because of the harsh physical conditions. Quite low survival rates of planted mangroves at the shoreline area were reported at the Visayas [4] and at other areas in the Philippines [5], as well as at Surat Thani [6] and at Samuth Songkram in Thailand [7]. Mangrove plantation in shoreline area leads to rapid accretion because the mangrove roots and pneumatophores effectively slow water movement and act as efficient sediment trappers [8]. Geomorphological process 
affects greatly this function of mangrove vegetation. However, mangroves explicitly promote sediment deposition, stimulate soil stability, and protect shoreline from erosion [3, 9-11]. The success of rehabilitation efforts largely depends on the early establishment of planted mangroves. After understanding the ecology of sites and adequate species as key issues for successful mangrove plantation, we shall head for the next step to enhance initial growth rates. Effects of nitrogen fertilizer on mangrove growths were identified in Florida, USA at the abandoned impoundment [12]. Also Matsui et al. (2010) revealed an importance of soil carbon in initial stage of mangrove growths [13]. Taking these into the account, soil amendment application will be effective in ensuring rapid initial growth. There is however still limited number of mangrove planting by the application of soil amendment, especially at shoreline area.

The objectives of this study are therefore: (1) to understand the growth characteristics of mangroves species planted upon highly eroded shorelines, (2) to assess the effectiveness of different soil amendments in promoting initial mangrove growth, and (3) to examine the pollution level of the study site from the viewpoints of water qualities and biological properties to determine the influence of the surrounding areas on the mangrove area.

\section{Methods}

2.1. Study Site. The study was conducted at an abandoned shrimp pond located close to the shoreline within the Samut Sakhon subdistrict/district, Samut Sakhon province, Thailand $\left(13^{\circ} 28^{\prime} \mathrm{N}, 100^{\circ} 13^{\prime} \mathrm{E}\right.$ ) (Figure 1). Annual tidal range monitored at Tha Chin station (Samut Sakhon province) is about $0.36-3.46 \mathrm{~m}$ above mean sea level. The wave height rises up as high as $4 \mathrm{~m}$ at monsoon seasons.

Most of the mangroves disappeared from the study site but some species such as Avicennia marina and Rhizophora mucronata remained to grow in the edges along the road and of the former shrimp ponds. Exploitation of the area began with the construction of saltpans in the 1970s, followed by shrimp farming in the 1980s and associated clear-felling of the majority of mangrove forests. In addition to the destruction of mangroves in the area, a drastic decline was reported in fishery yields. Local fishermen reported that greater numbers of cockles and catfish were harvested prior to the largescale conversion of mangroves to shrimp ponds. Today, few catfish are harvested in the area.

2.2. Outline of Coastal Erosion at Samut Sakhon. The location of the shoreline is generally determined by the dynamic balance between sedimentation and erosion. Accordingly, changes in sedimentation patterns affect the dynamic balance of the shoreline. At Nakhon Sawan (Figure 1), sediment loading was monitored for 33 years from 1960 to 1993 [14]. Figure 2 shows the changes in total sediment loading during this period. Sediment loading was variable during the period up to 1970 , but subsequent to this time the total amount of sediment has gradually decreased, falling below $10^{11}$ metric tons per year for every year after 1976 except 1987. The
Bhumibol Dam was constructed in 1964 and the Sirikit Dam became operational in 1974 after a 9-year construction period from 1963 to 1972 (Figure 1). It is likely that dam construction resulted in reduced sediment loading into the Gulf of Thailand.

Sedimentation in this area is highest in September and October when peak rainfall occurs (Figure 3). The sediment patterns or the upstream area of the Chao Phraya River between 1942 and 1988 (Figure 3) resembles the pattern of rainfall distribution; however, there is likely to be an approximately 1-month time lag between rainfall and related sedimentation. For example, the highest rainfall is recorded in September, while the maximum sedimentation is recorded a month later in October.

Severe wave attack is concentrated in the period from March to the middle of May, although above-average wave action continues until the end of September [15]. As stronger wave attack leads to increased damage to planted mangroves, special attention should be given to these months to protect mangroves from wave damage.

The effects of wind and/or wave attack on the coast are more severe if mangrove forests have been cleared. The shoreline in the study region is retreating at a rate of $20 \mathrm{~m} \mathrm{y}^{-1}$ [15], which is much higher than the figure of $3.6 \mathrm{~m} \mathrm{y}^{-1}$ recorded in the eastern part of the Thai Gulf [16]. According to a feasibility study conducted by SEATEC and BEST [17] on a $14 \mathrm{~km}$ stretch of coastline in this area, the shoreline retreated by $127 \mathrm{~m}$, equivalent to $1,105 \mathrm{rai}(1 \mathrm{rai}=40 \times 40 \mathrm{~m})$, during the 7 -year period from 1987 to 1994 , and retreated by $351 \mathrm{~m}$ (3,056 rai) during the 25-year period from 1969 to 1994 .

2.3. Mangrove Plantation and Tree Measurements. A total of approximately 14,000 Rhizophora mucronata (RM) seedlings were planted over an area of approximately 6 ha in September 2001. Subsequently, tree height was measured on five occasions: June 2002, January 2003, June 2003, January 2005, and October 2005, representing periods of 9 months, 1 year and 3 months, 1 year and 8 months, 3 years and 3 months, and 4 years after planting, respectively. To monitor the planted trees, we designated three plots within the plantation site (Figure 4). Each plot contains 8 lines of 25 trees with a total number of 200 .

2.4. Soil Amendment Application. At sites of severe coastal erosion, it is important to induce the rapid growth of planted mangroves, especially during the initial growth stages. To this end, we applied three types of soil amendment: NPK, humic acid, and coconut fiber to 50 trees, respectively, at three plots. Coconut fiber is mixed into the seedling pot in Thai governmental mangrove nurseries to improve soil physical condition. Mangrove ecosystems were identified as either nitrogen $(\mathrm{N})$ or phosphorus (P) limited [18]; hence NPK was applied in this study to enhance initial growth of mangroves. Contents of organic carbon influence initial growths of Rhizophora apiculata [13] so that humic acid as the fast-acting organic carbon was applied. Analysis of variance (ANOVA) was applied to examine the difference of three types of soil amendment as well as to examine the effects of locality on 


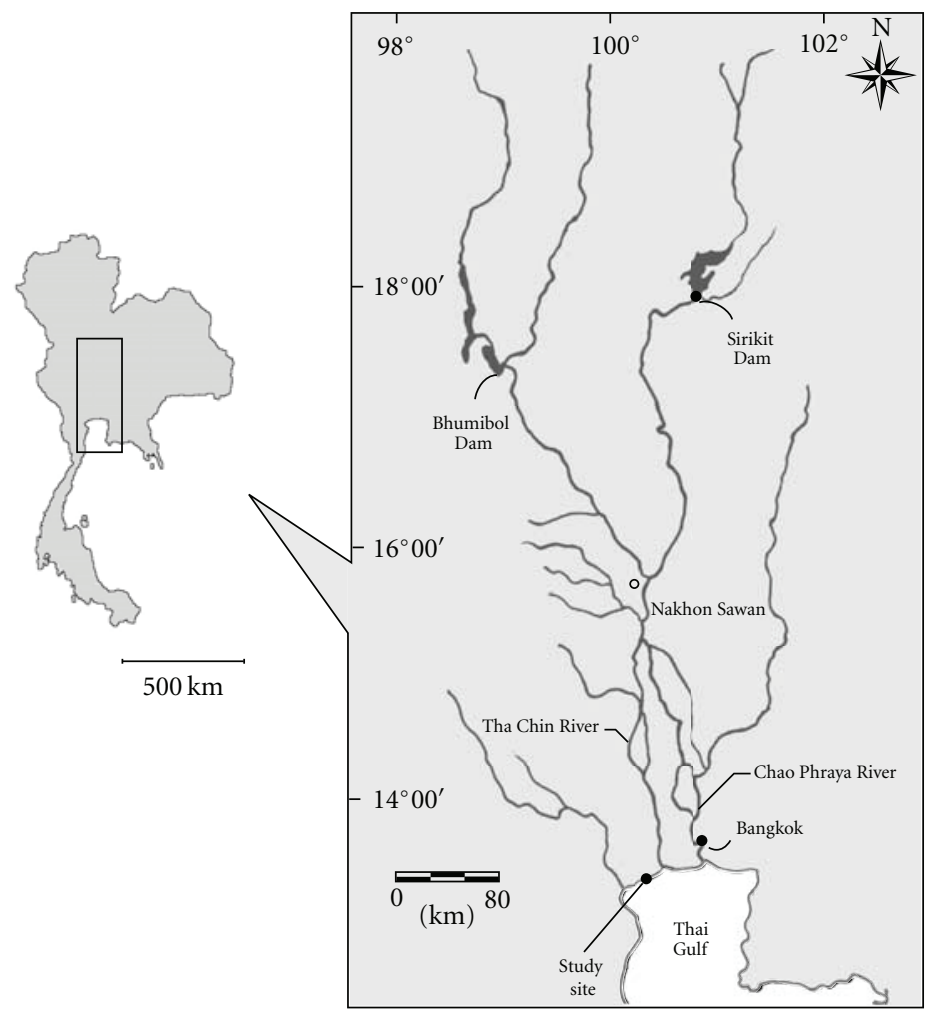

FIgure 1: Location of the study site. Samut Sakhon province, Thailand.

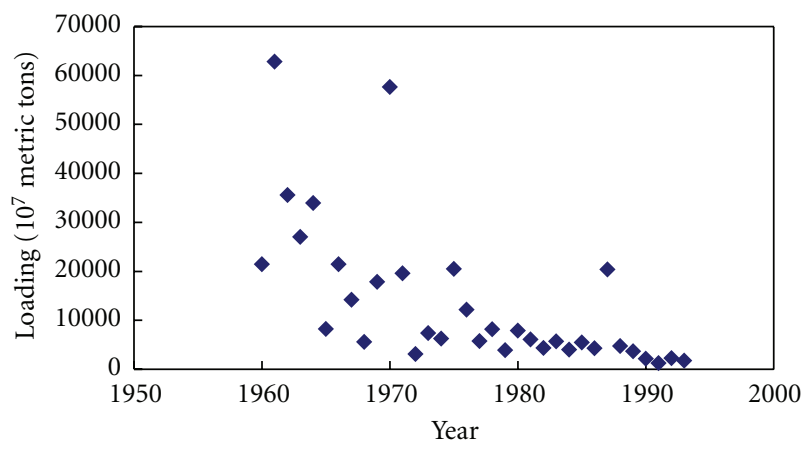

FIGURE 2: Total sediment loading at Nakhon Sawan from 1960 to 1993 (cited from [1]).

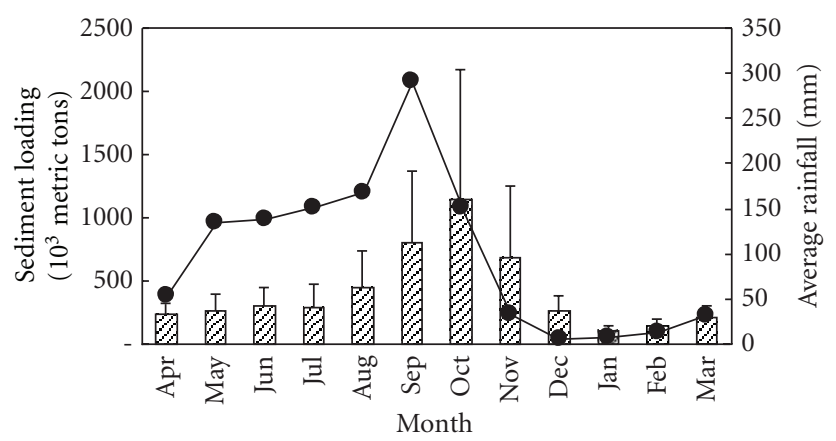

Sediment loading

$\rightarrow$ Average rainfall

Figure 3: Average monthly sediment loading at Nakhon Sawan from 1976 to 1993 excluding the data of 1987 (Error bars denote standard deviation) and average rainfall (mm) within the Chao Phraya River basin between 1942 and 1988 (cited from [1]). 


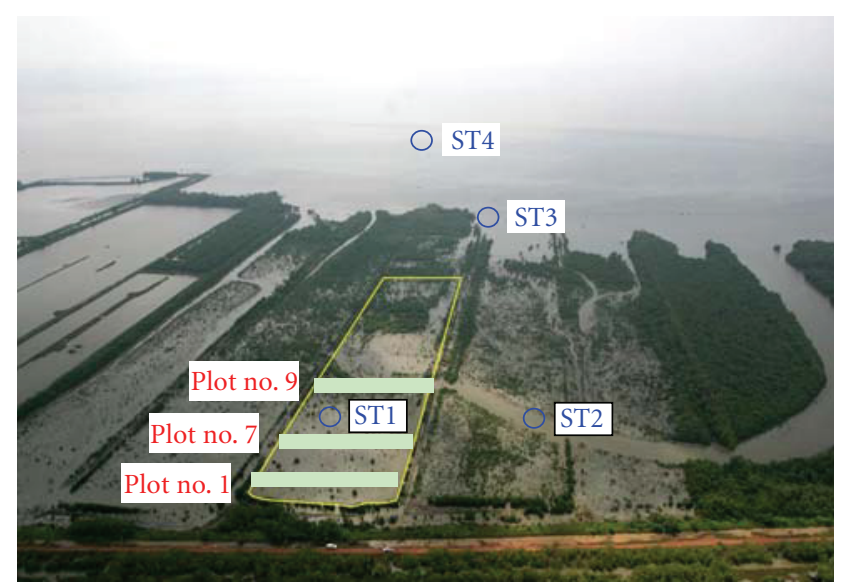

FIGURE 4: View of the study site taken by remote-controlled helicopter from $500 \mathrm{~m}$ above sea level. The enclosed area shows the location of the study site (approximately $6 \mathrm{ha}$ ). Blue circles show the stations where the samples were taken for measurements of water, sediment, and biological properties.

mangrove growth by the statistical software JMP 8.0.2. The statistical significance of differences was determined by ANOVA followed by a multiple comparison test (TukeyKramer test) at 95\% significance level $(P<0.05)$.

\subsection{Water/Sediment Sampling and Biological Measurements.} Water was collected from the study site (ST1) and an offshore station (ST4) (Figure 4) and transported to the laboratory while kept chilled. The water samples were analyzed for temperature, dissolved oxygen, salinity, $\mathrm{pH}$, ammoniacal-nitrogen $\left(\mathrm{NH}_{4}^{+}\right.$plus $\left.\mathrm{NH}_{3}\right)$, nitrite-nitrogen, nitrate-nitrogen, total dissolved nitrogen (TDN), dissolved organic nitrogen $(\mathrm{DON})$, particulate organic nitrogen $(\mathrm{PON})$, total nitrogen (TN), dissolved inorganic phosphorus (DIP), total dissolved phosphorus (TDP), dissolved organic phosphorus (DOP), particulate phosphorus (PP), total phosphorus (TP), particulate organic carbon (POC), chlorophyll $a$, and biological oxygen demand (BOD). All of the above water analyses were conducted according to the standard methods [19].

Sediment samples collected at the study site (ST1), a nearby study site (ST2), the edge of shoreline (ST3), and an offshore station (ST4) were analyzed for ammoniacal-nitrogen, nitrite-nitrogen, nitrate-nitrogen, phosphorus, total phosphorus (the sum of all forms of phosphorus), total nitrogen, organic carbon, and acid volatile sulfide (AVSS). Ammoniacal-nitrogen was measured by the phenolhypochlorite method [20]. Nitrate and nitrite were determined together using the cadmium reduction method on a flow injection analyzer (Lachat QuikChem 8000). Phosphorus was analyzed using the spectrophotometric method [21] while total phosphorus was analyzed by ash/acid extraction [22]. Nitrogen and organic carbon were analyzed according to the high temperature combustion method using $\mathrm{CHN}$ elemental analyzer (LECO CHN-900) [23]. AVS-S was analyzed from the surface sediment using $\mathrm{H}_{2} \mathrm{~S}$ absorbent columns (GASTEC, Kanagawa, Japan) according to the procedure described in Tsutsumi and Kikuchi (1983) [24]. The texture of each sediment sample was determined using the hydrometer method.
The abundance of plankton was measured from samples collected in a $40 \mu \mathrm{m}$ mesh plankton net and preserved in 5\% formalin solution. The biomass of phytoplankton was studied according to the enumeration method and chlorophyll $a$ content. Benthos abundance was calculated from the number of benthic animals retained after passing the sample through a $0.5 \mathrm{~mm}$ benthos sieve; collected animals were preserved in $10 \%$ formalin solution.

\section{Results}

3.1. Survival Rate and Tree Growth. The survival and growth rates of planted mangroves have varied since the mangroves were planted in September 2001. In October 2005, 4 years after planting, the survival rate decreased in the order of Plot $1>$ Plot $7>$ Plot 9, with survival rates of $63.5 \%, 50.0 \%$, and $26.7 \%$, respectively (Figure 5 ). The survival rate varied with distance from the shoreline and may correspond to the intensity of wave attack. As Plot 9 was located at the most offshore, it experienced the most severe erosion resulting from wind and wave action, thereby resulting in the lowest survival rate of the measured plots. Changes in the survival rates for all plots were relatively minor over the first 3 years after planting, but the survival rate for Plot 9 began to decrease markedly from January 2005, 3 years and 3 months after planting. The survival rate for Plot 1 oddly increased in Oct 2005 from that of Jan 2005, which is because the trees identified as dead in Jan 2005 had revived in Oct 2005.

Tree heights measured 4 years after planting (October 2005) were greatest in Plot 1, with an average height of $308 \mathrm{~cm}$. Mangrove showed the highest growths where the survival rate was highest, indicating that growth and survival conditions were interrelated. Tree heights 4 years after planting were greater in Plot $9(248 \mathrm{~cm} \pm 61.6 \mathrm{~cm})$ than in Plot 7 $(214 \mathrm{~cm} \pm 96.7 \mathrm{~cm})$, possibly due to different degree of wave/ wind attack between the two plots. It is thus speculated that physical conditions were critical for the survival and growth of mangroves in the study region.

We also established an experimental Rhizophora plantation within an abandoned shrimp pond at Nakorn Sri 


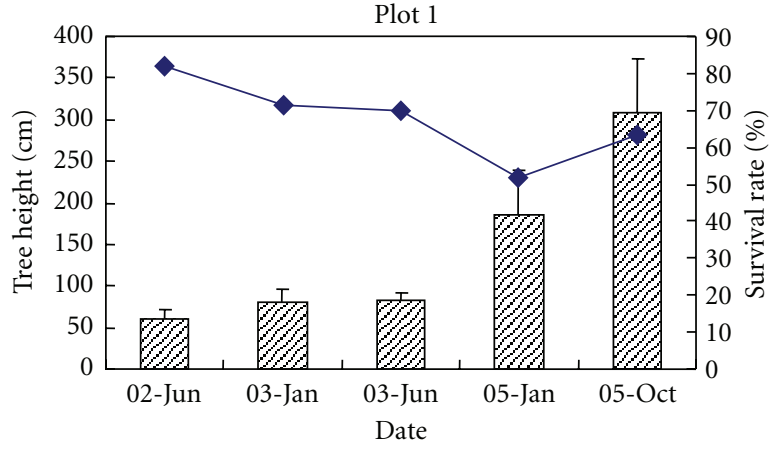

(a)

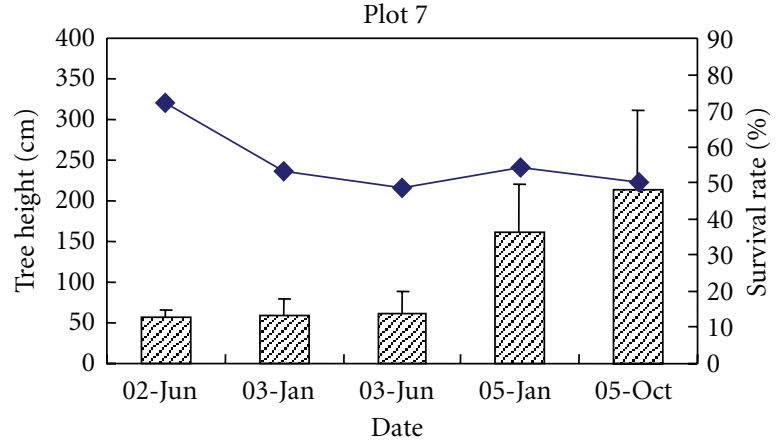

(b)

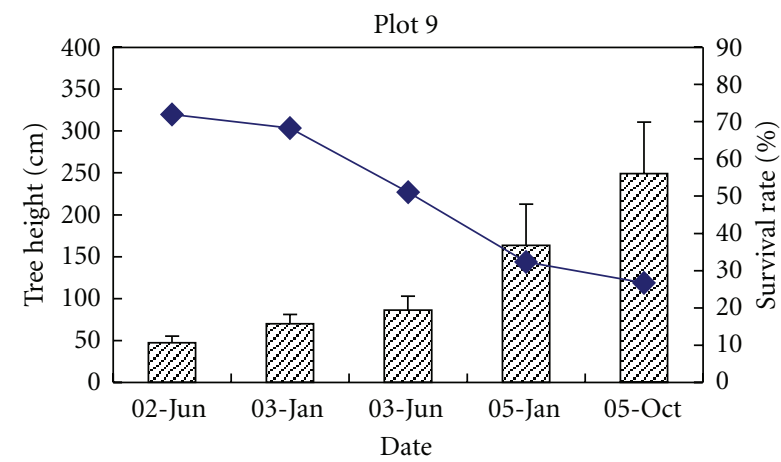

ZZ Mean height

- Survival rate

(c)

FIGURE 5: Survival and growth of planted mangroves measured in June 2002, January 2003, Jun 2003, January 2005 , and October 2005. Locations of the plots are shown Figure 4. Error bars denote standard deviation.

Thammarat, $700 \mathrm{~km}$ south of the present study site. The southern site recorded a low frequency of tidal inundation, and tree heights measured 4 years after planting were around $200 \mathrm{~cm}$ [13]. Accordingly, the average height of $308 \mathrm{~cm}$ measured in the present study could indicate that growing conditions of the study site were relatively favorable in terms of nutrient supply or local hydrology.

3.2. Soil Amendment Application. Plots to which the three types of soil amendment were applied showed higher growth rates than the unfertilized control plot (Figure 6). In ANOVA we found significant difference in tree heights among the three types of soil amendment at each measurement from the first (June 2002) to the last (October 2005) despite no apparent difference in the means (Figure 6). Effect of soil amendment on tree height was most significant in NPK treatment at Plot 1 and Plot 9 while so in the coconut fiber treatment at Plot 7. Lower tree heights in Plot 7 than Plot 9 (Figure 5) assured that growing condition was harsher in Plot 7. Coconut fiber would have amended to stabilize erodible soils of Plot 7 which was more effective than NPK and humic acid.

If soil amendment effect with either NPK or coconut fiber was noticed in the first measurement (June 2002), its effect had continued to the subsequent measurements till the last measurement (October 2005). This suggests that fertilization of mangrove plants in early stage is important when they are planted in eroded area. It appears that the effects of soil amendment are more pronounced in landward areas where erosion is less severe. In terms of cost-effectiveness, fertilization therefore would be recommendable to be done first in landward areas.

3.3. Water Quality. pH values were lowest at ST1, while salinity levels were almost similar at all sampling sites (Table 1). The low $\mathrm{pH}$ recorded at ST1 could have resulted from the high concentrations of POC at this site. Large amounts of organic matter were produced by mangroves which were then decomposed and consequently acted to lower the $\mathrm{pH}$ at ST1.

DON and PON were major nitrogen compounds as shown by higher concentrations than inorganic nitrogen compounds (ammoniacal-nitrogen, nitrite-nitrogen, and nitrate-nitrogen). The concentrations of chlorophyll $a$ ranged from 11.3 to 28.1 in ST1 and from 8.4 to $16.3 \mu \mathrm{g} \mathrm{L}^{-1}$ in ST4. Possible correlation between PON and chlorophyll $a$ indicated that PON was originated from plankton [25]. Concentrations of chlorophyll $a$ fluctuated seasonally with the high concentration in April 2001 and with the relatively low concentration at other times. 


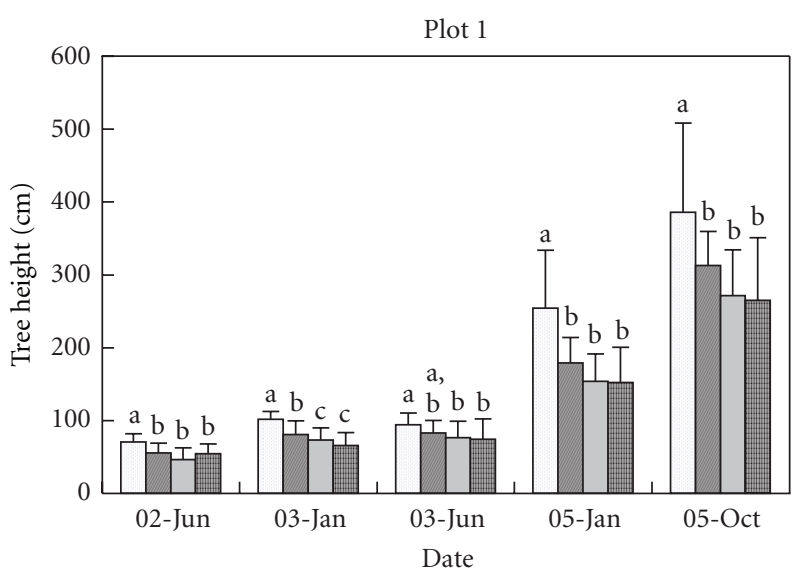

(a)

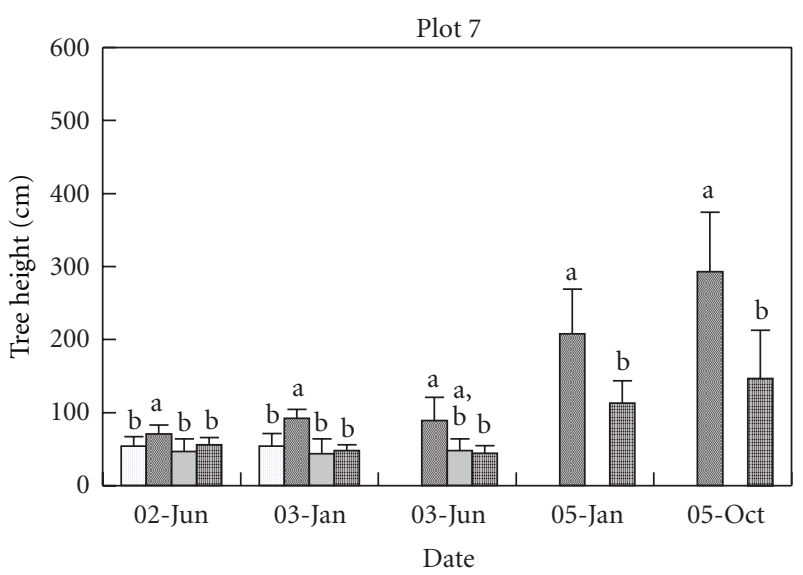

(b)

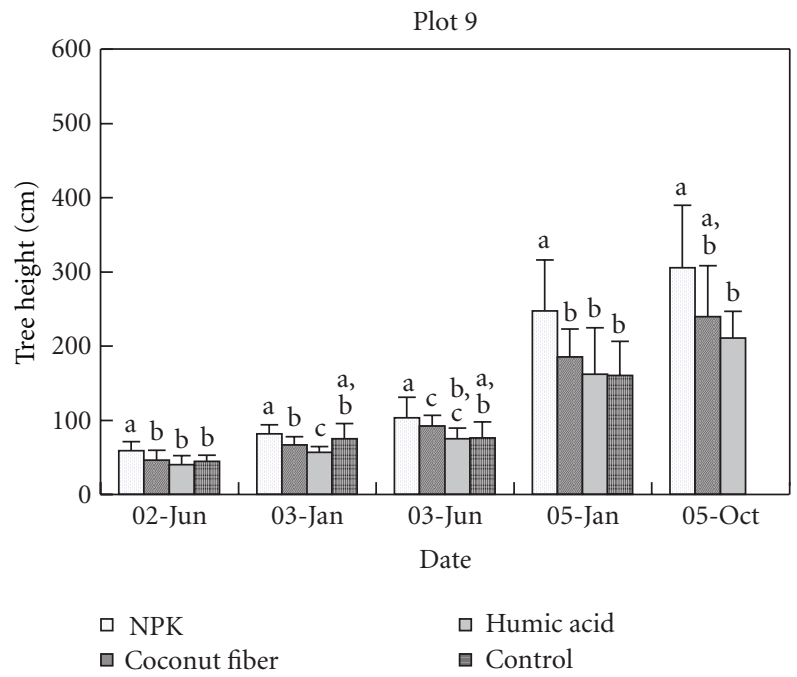

(c)

Figure 6: Effects of the fertilizer application on tree heights of June 2002, January 2003, Jun 2003, January 2005, and October 2005. Error bars denote standard deviation. Different letters are significantly different at $P<0.05$ by the Tukey-Kramer test.

BOD was high in all measurements, indicating that the study site was heavily polluted (Table 1). Tookwinas reported that the average BOD of effluent from shrimp ponds was $8.47 \mathrm{mg} \mathrm{L}^{-1}$ [26]. At the mangrove plantation site (ST1), BOD was $4.3 \mathrm{mg} \mathrm{L}^{-1}$ when measured in August 2001, and $4.9 \mathrm{mg} \mathrm{L}^{-1}$ in December 2001. These values, being approximately half of those for effluent from shrimp ponds, indicated that the mangrove plantation site has been subjected to the inflow of polluted water from adjacent sites or from the Tha Chin and Chao Phraya rivers (Figure 1).

The TN concentration at ST1 $\left(1.9,4.3 \mathrm{mg} \mathrm{N}^{-1}\right)$ was higher than that at ST4 $\left(1.8,2.7 \mathrm{mg} \mathrm{N} \mathrm{L}^{-1}\right)$, with these values being higher than the average value for Kung Krabaen Bay, Chantaburi province $\left(0.4-0.5 \mathrm{mg} \mathrm{N} \mathrm{L}^{-1}\right)$ and lower than values recorded from effluent water sampled from an intensive shrimp pond (4.9 $\left.\mathrm{mg} \mathrm{N} \mathrm{L}^{-1}\right)$ [26]. Values of TP, PP, and TDP were also higher at ST1, suggesting that the loadings were derived from external sources. Similarly, as for nitrogenous compounds, all phosphorous compounds (TDP, DOP, PP, TP, POC) also increased in December 2001 from April
2001, probably reflecting the high loading of effluent from the surroundings of the study site.

The levels of chlorophyll $a$ at the plantation site (ST1) were higher than those in the offshore area (ST4), indicating that a primary producer (phytoplankton) was generated at the plantation site. Levels of chlorophyll $a$ showed temporal fluctuations, being especially high in April 2001 but relatively low at other times. Levels of BOD varied between 4.3 and $4.9 \mathrm{mg} \mathrm{L}^{-1}$ at the plantation site, probably reflecting the influence of effluent from outside of the plantation site.

3.4. Sediment Quality. Nitrogen levels were relatively high in the mangrove plantation area. Ammoniacal-nitrogen was dominant over nitrate-nitrogen and nitrite-nitrogen, indicating reducing conditions in the sediment (Table 2). The sulfide content was relatively high in December 2001, reflecting the spontaneous input of organic matter from other sites and the resulting increase in reducing conditions. Levels of nitrate-nitrogen, which is the reduced form of nitrogen, also 
TABLE 1: Results of water analyses conducted in April 2001, December 2001, and June 2002.

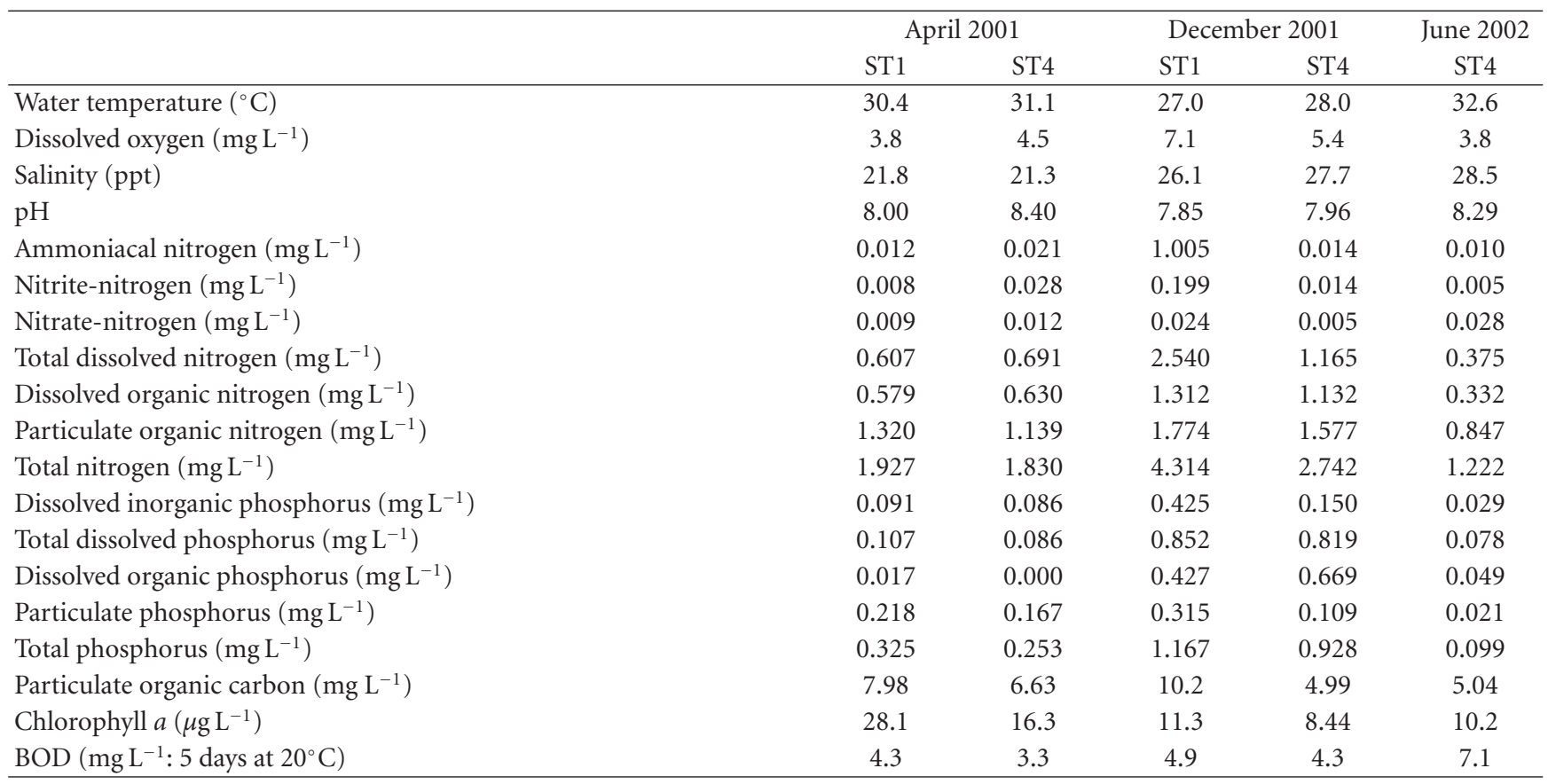

Table 2: Results of sediment analyses conducted in April 2001, December 2001, and June 2002.

\begin{tabular}{|c|c|c|c|c|c|c|c|c|c|}
\hline Date & Station & $\begin{array}{c}\text { Total } \\
\text { nitrogen } \%\end{array}$ & $\begin{array}{c}\text { Ammoniacal- } \\
\text { nitrogen } \\
\mathrm{mg} \mathrm{kg}^{-1}\end{array}$ & $\begin{array}{l}\text { Nitrite- } \\
\text { nitrogen } \\
\mathrm{mg} \mathrm{kg}^{-1}\end{array}$ & $\begin{array}{c}\text { Nitrate- } \\
\text { nitrogen } \\
\mathrm{mg} \mathrm{kg}^{-1}\end{array}$ & $\begin{array}{c}\text { Total } \\
\text { phosphorus } \\
\mathrm{mg} \mathrm{kg}^{-1}\end{array}$ & $\begin{array}{c}\text { Available } \\
\text { phosphorus } \\
\text { mg kg-1 }\end{array}$ & $\begin{array}{c}\text { Total } \\
\text { organic } \\
\text { carbon } \%\end{array}$ & $\begin{array}{l}\text { AVS-S } \\
\mathrm{mg} \mathrm{kg}^{-1}\end{array}$ \\
\hline \multirow{4}{*}{ April 2001} & ST1 & 0.27 & 59.8 & 0.04 & 3.41 & 45.3 & 5.17 & 2.52 & 25.0 \\
\hline & ST2 & 0.30 & 112 & 0.06 & 4.20 & 44.6 & 18.1 & 2.70 & 77.3 \\
\hline & ST3 & 0.02 & 63.4 & 0.16 & 5.74 & 55.3 & 10.3 & 1.18 & 77.8 \\
\hline & ST4 & 0.04 & 47.0 & 0.04 & 3.25 & 86.9 & 8.79 & 0.97 & 214 \\
\hline \multirow{4}{*}{ December 2001} & ST1 & 0.27 & 41.8 & 0.23 & 6.55 & 52.1 & 8.13 & 2.08 & 257 \\
\hline & ST2 & 0.31 & 91.9 & 0.33 & 8.36 & 80.4 & 27.2 & 2.36 & 213 \\
\hline & ST3 & 0.25 & 146 & 0.15 & 2.74 & 44.8 & 18.9 & 2.03 & 146 \\
\hline & ST4 & 0.26 & 42.1 & 0.15 & 2.46 & 88.7 & 10.4 & 2.02 & 92.1 \\
\hline \multirow{4}{*}{ June 2002} & ST1 & 0.14 & 24.8 & 0.03 & 4.53 & 31.0 & 6.64 & 1.49 & 30.5 \\
\hline & ST2 & 0.20 & 25.9 & 0.00 & 5.11 & 35.7 & 9.57 & 2.06 & 51.4 \\
\hline & ST3 & 0.12 & 16.2 & 0.03 & 3.68 & 16.2 & 13.8 & 1.47 & 57.7 \\
\hline & ST4 & 0.15 & 20.6 & 0.11 & 2.77 & 30.2 & 2.17 & 1.97 & 134 \\
\hline
\end{tabular}

increased at this time. Constantly high levels of sulfide at ST4 indicate large amounts of organic matter, even in the offshore areas.

In June 2002, reducing conditions were measured in the offshore area (ST4), probably due to effluent from major rivers. Considering that typical coastal sediment in Thailand contains $1.06 \%$ organic carbon and $0.05 \%$ total nitrogen [26], the mangrove plantation site (including the offshore area) experienced a high degree of eutrophication at this time. Available P was higher at ST2 than at ST1. Since ST2 is located in the middle of a small creek, we consider that phosphorus was transported along the creek from offshore areas.

3.5. Benthos. The abundance and species composition of benthos varied considerably at each measurement period; however, values were generally higher during the monsoon season (April, June) than during the dry season (December) (Table 3). Environmental factors such as sediment composition [27] and salinity [28] affected the benthic community. Sediment texture coarsened in the order of ST $1<$ ST $2<$ ST $3<$ ST4 (Table 4); the number of species and abundance also increased in this order (Table 3). The diversity of Polychaeta has been reported to be related to the degree of salinity of the host sediment $[29,30]$. In this study, Polychaeta was dominant at ST1 during the monsoon season when the influence of salinity was relatively minor while the diversity of Crustacea increased with lower salinity.

3.6. Phytoplankton. We identified 3 groups and 33 genera of plankton (Table 5). The blue-green algae group yielded 
TABLE 3: Species of benthic fauna and abundance (individuals $/ \mathrm{m}^{2}$ ) within sediment and bottom of the replanted mangrove areas.

\begin{tabular}{|c|c|c|c|c|c|c|c|c|c|c|}
\hline & \multirow[b]{2}{*}{ No. } & \multirow[b]{2}{*}{ Group } & \multicolumn{2}{|c|}{ April 2001} & \multicolumn{4}{|c|}{ December 2001} & \multicolumn{2}{|c|}{ June 2002} \\
\hline & & & ST1 & ST4 & ST1 & ST2 & ST3 & ST4 & ST3 & ST4 \\
\hline \multirow{4}{*}{ Crustacea } & 1 & Balanus & & 133 & & & & & & \\
\hline & 2 & Leucosia & & 44 & & & & & & \\
\hline & 3 & Nassarius & & & & & 30 & & & \\
\hline & 4 & Uca spp. & & & 15 & & & & & \\
\hline \multirow{2}{*}{ Gastopoda } & 1 & Littorina & & 89 & & & 15 & & & \\
\hline & 2 & Paludinella & & & 30 & & & & & \\
\hline \multirow{7}{*}{ Pelecypoda } & 1 & Anadana & & 44 & & & & & & \\
\hline & 2 & Mactra & & 178 & & & & & & 134 \\
\hline & 3 & Musculus & & 222 & & & & & & \\
\hline & 4 & Mytella & & 89 & & & & & & \\
\hline & 5 & Pholas spp. & & & & & 2,682 & & & \\
\hline & 6 & Tellina & 89 & 533 & & 15 & 30 & & 134 & \\
\hline & 7 & Tellina foliacea & & & & & & 15 & & \\
\hline \multirow{10}{*}{ Polychaeta } & 1 & Aquilaspio & 133 & & & & & & & \\
\hline & 2 & Cerithium & 44 & & & & & & & \\
\hline & 3 & Glycera & 267 & & & & & & & \\
\hline & 4 & Eunic & 133 & 1,689 & & & & & 400 & \\
\hline & 5 & Nephytys & 356 & & & & & & & \\
\hline & 6 & Nereis & & & & & 504 & 445 & 1,067 & 1,600 \\
\hline & 7 & Notomastus & 578 & & & & & & & \\
\hline & 8 & Polyodontes & & 222 & & & & & & \\
\hline & 9 & Sabella & & 267 & & & & & & \\
\hline & 10 & Sigambra & 667 & & & & & & & \\
\hline
\end{tabular}

TABLE 4: Results of texture analysis.

\begin{tabular}{lcccc}
\hline Station & Clay $(\%)$ & Silt $(\%)$ & Sand $(\%)$ & Type \\
\hline ST1 & 49.7 & 19.3 & 31.1 & Clay \\
ST2 & 35.1 & 27.6 & 37.3 & Clay loam \\
ST3 & 28.8 & 31.2 & 40.1 & Clay loam \\
ST4 & 14.2 & 29.3 & 56.5 & Sandy loam \\
\hline
\end{tabular}

5 genera, green algae 3, and diatoms 25. Except for ST1 in April 2001, diatoms were the dominant group in terms of the number of species and the number of genera. Diatoms bloomed at the low rainfall periods (December 2001), with the increased number of genera to 12 genera and of the total cell number to 62,837 cells. At the most offshore site (ST4), the number of phytoplankton genera and of total phytoplankton cells increased in the order of April 2001 (9 genera, 3,164 cell L ${ }^{-1}$ ), December 2001 (13 genera, 66,922 cell L $^{-1}$ ), and June 2002 (15 genera, 33,201 cell L ${ }^{-1}$ ). This trend appears to correspond to the salinity level: a greater number of genera occurred during the periods of higher salinity. Similar trends have been reported for diatoms (the greater number of genera during the periods of low precipitation and at the sites with the higher salinity) in Songkhla Lake, Thailand [31].
The species composition of phytoplankton was related to the water quality. In December 2001, the water was eutrophicated as reflected by the higher contents of phosphorus and nitrogen (Table 1). Under these conditions, diatoms became dominant at the expense of other groups.

\section{Discussion}

Nitrogen fertilization is reported to increase growth rates of mangroves which were planted in an abandoned impoundment in Florida [32] while our study showed that fertilization was also effective in the open area with high-energy environments.

Establishment of mangroves in heavily eroded environments has been difficult. Total area losses accounted for $0.91 \mathrm{~km}^{2} \mathrm{y}^{-1}$ for the Thai Gulf coast. However the presence of mangroves reduces the erosion rates in areas where erosion prevailed $[33,34]$. Enhancement of initial mangrove growth through soil amendment therefore should be an effective way to reduce erosion rates at heavily eroded places. The effects of soil amendment are limited if the plantation site is heavily eroded, as the case of Plot 7 in the present study. This suggests that the planting of mangroves along eroded shorelines should be initiated within the least erosion-prone areas.

Physical measures can be undertaken to protect seedlings from wave/wind attack; however, this approach is ineffective 
TABLE 5: Results of phytoplankton (cell L-1) measurement conducted in April 2001, December 2001, and June 2002.

\begin{tabular}{|c|c|c|c|c|c|c|c|}
\hline \multirow[b]{3}{*}{ Phytoplankton group } & \multirow[b]{3}{*}{ No. } & \multirow[b]{3}{*}{ Genera } & \multicolumn{5}{|c|}{ Density of phytoplankton $\left(\right.$ cell $\left.\mathrm{L}^{-1}\right)$} \\
\hline & & & \multicolumn{2}{|c|}{ April 2001} & \multicolumn{2}{|c|}{ December 2001} & \multirow{2}{*}{$\begin{array}{c}\text { June } 2002 \\
\text { ST4 }\end{array}$} \\
\hline & & & ST1 & ST4 & ST1 & ST4 & \\
\hline \multirow{5}{*}{ Blue green algae } & 1 & Anabaenopsis & 397 & & & & \\
\hline & 2 & Oscillatoria & 1,008 & 336 & & & 225 \\
\hline & 3 & Gloeocapsa & 14,463 & & & & \\
\hline & 4 & Lyngbya & & 140 & & & \\
\hline & 5 & Spirulina & 117 & & & & 24 \\
\hline \multirow{3}{*}{ Green algae } & 1 & Gonatozygon & 332 & & & & \\
\hline & 2 & Schroederia & 91 & 14 & & & \\
\hline & 3 & Staurastrum & 117 & & & & \\
\hline \multirow{25}{*}{ Diatoms } & 1 & Skeletonema & 2,581 & 462 & & & 7,125 \\
\hline & 2 & Coscinodiscus & 11,427 & 742 & 827 & 22 & 18 \\
\hline & 3 & Dactyliosolen & & & & 11 & 33 \\
\hline & 4 & Rhizosolenia & 468 & 882 & 30,645 & 8,974 & 1,410 \\
\hline & 5 & Bacteriastrum & & & & 33 & 13,688 \\
\hline & 6 & Chaetoceros & 273 & & 7,425 & 22,000 & 8,250 \\
\hline & 7 & Odontella & & & 281 & 28 & 51 \\
\hline & 8 & Thalassionema & & & 6,210 & 72 & 1,185 \\
\hline & 9 & Gyrosigma & & & 146 & & 27 \\
\hline & 10 & Navicula & 163 & 252 & 11 & 44 & \\
\hline & 11 & Nitzschia & 345 & & & & \\
\hline & 12 & Pseudonitzschia & & & 17,145 & 35,132 & \\
\hline & 13 & Campylodiscus & & & 11 & & \\
\hline & 14 & Dictyocha & & & & & 3 \\
\hline & 15 & Noctiluca & & & & & 1,050 \\
\hline & 16 & Ceratium & & & & & 105 \\
\hline & 17 & Alexandrium & & & & & 6 \\
\hline & 18 & Fragilaria & 137 & 238 & & & \\
\hline & 19 & Eucampia & & & 11 & 6 & \\
\hline & 20 & Melosira & 245 & & & & \\
\hline & 21 & Hemiaulus & & & 11 & 44 & \\
\hline & 22 & Pleurosigma & 124 & 98 & 114 & & \\
\hline & 23 & Pseudosolenia & & & & 550 & \\
\hline & 24 & Thalassiosira & & & & 6 & \\
\hline & 25 & Stephanodiscus & 98 & & & & \\
\hline
\end{tabular}

in most cases. We erected bamboo fencelines at other study sites to protect mangrove seedlings from wave/wind attack, but the fences lasted no more than 1 year. The construction of physical barriers is also extremely expensive. According to the Japan International Cooperation Agency (JICA) study, the planting of mangroves across the 4,800 m shoreline of the present study area using civil engineering techniques to prevent coastal erosion will cost 983 million baht (approximately 31 million US dollars as of July 2011) [15]. In Malaysia, a $90 \mathrm{~m}$ long rubble mound structure (breakwater) was constructed along an eroding tropical shoreline at a cost of US\$ 42,850 which is more than 10 times lower [35]. This kind of cost is quite variable according to the sort of construction method which is adopted. However civil engineering operation for coastal protection is generally rather expensive.

The disastrous tsunami that hit the Thailand coast in December 2004 revealed the important role mangroves play in terms of coastal protection. It appears that areas covered in mangroves suffered less damage than mangrove-free areas, and the protective effect of mangroves against tsunami damage differed among different species. Kamali and Hashim (2011) reported that Rhizophora spp. were found to have a greater protective effect than Sonneratia or Avicennia spp. [35]. These differences are attributed to root architecture, as the prop roots of Rhizophora spp. are stronger than the cable roots of Sonneratia and Avicennia spp. 
As any reduction in sediment supply from the major rivers is likely to influence the retreat of the coastline in the study region, complete protection against coastal erosion is not possible; however, the planting of mangroves is a potentially effective measure in lowering the present erosion rate. Mangrove-planting techniques should therefore be developed to cope with coastal erosion, especially in terms of adequate species selection, site identification, and additional measures such as soil amendment application.

The study site was highly polluted as indicated by water, sediment, and biological measurements, which could be influenced by the surrounding areas. Mangrove soils have a large buffering capacity for pollutants [36]. However, its capacity has a limit. With excessive loadings, mangrove soil can no longer retain pollutants, and consequently marine ecology and fishery resources will be severely damaged. Considering the pollution level of the study area, it should be necessary to watch carefully a status of pollution level of mangrove area in order to prevent drastic marine pollution.

\section{References}

[1] JAM, "Development and dissemination of re-afforestation techniques of mangrove forests," in Proceedings of the Workshop on ITTO Project, p. 216, Japan Association for Mangroves, NATMANCOM, Bangkok, Thailand, 1994.

[2] "Ecology and management of mangrove restoration and regeneration in East and Southeast Asia," in Proceedings of the 4th ECOTONE, C. Khemnark, Ed., Surat Thani, Thailand, 1995.

[3] C. D. Field, Ed., Restoration of Mangrove Ecosystems, International Society for Mangrove Ecosystems, Okinawa, Japan, 1996.

[4] Silliman University, Assessment of the Central Visayas Regional Project-1: Nearshore Fisheries Component, Silliman University Marine Laboratory, Dumaguete City, Philippines, 1996.

[5] J. H. Primavera and J. M. A. Esteban, "A review of mangrove rehabilitation in the Philippines: successes, failures and future prospects," Wetlands Ecology and Management, vol. 16, no. 5, pp. 345-358, 2008.

[6] S. Angsupanich and S. Havanond, "Effects of barnacles on mangrove seedling transplantation at Ban Don Bay, Southern Thailand," in Proceedings of the Tropical Forestry in the 21st Century, (FORTROP '96), pp. 72-81, Kasetsart University, Bangkok, Thailand, 1996.

[7] P. Sakunathawong, "Mangrove planting on new mudflats at Tambon Klong Khon, A. Muang, Samut Songkram," in Proceedings of the 9th National Seminar on Mangrove Ecology, p. 9, 1995.

[8] C. Woodroffe, "Mangrove sediments and geomorphology," in Tropical Mangrove Ecosystems. Coastal and Estuarine Studies 41, A. I. Robertson and D. M. Alongi, Eds., pp. 7-41, American Geophysical Union, Wash, USA, 1992.

[9] P. G. E. F. Augustinus, "Geomorphology and sedimentology of mangroves," in Geomorphology and Sedimentology of Estuaries. Developments in Sedimentology 53, G. M. E. Perillo, Ed., pp. 333-357, Elsevier Science, Amsterdam, The Netherlands, 1995.

[10] K. Furukawa and E. Wolanski, "Sedimentation in mangrove forests," Mangroves and Salt Marshes, vol. 1, no. 1, pp. 3-10, 1996.

[11] J. M. Smoak and S. R. Patchineelam, "Sediment mixing and accumulation in a mangrove ecosystem: evidence from ${ }^{210} \mathrm{~Pb}$,
${ }^{234}$ Th and ${ }^{7}$ Be," Mangroves and Salt Marshes, vol. 3, no. 1, pp. 17-27, 1999.

[12] I. C. Feller, D. F. Whigham, K. L. McKee, and C. E. Lovelock, "Nitrogen limitation of growth and nutrient dynamics in a disturbed mangrove forest, Indian River Lagoon, Florida," Oecologia, vol. 134, no. 3, pp. 405-414, 2003.

[13] N. Matsui, J. Suekuni, S. Havanond, A. Nishimiya, J. Yanai, and T. Kosaki, "Determination of soil-related factors controlling initial mangrove (Rhizophora apiculata BL.) growth in an abandoned shrimp pond," Soil Science and Plant Nutrition, vol. 54, no. 2, pp. 301-309, 2008.

[14] Royal Irrigation Department, Government of Thailand, History of Water Resources Development in Thailand, 2002.

[15] SANYU and PANTA, "The feasibility study on mangrove revival and extension project in the Kingdom of Thailand," JICA Report, 2001.

[16] U. Thampanya, J. E. Vermaat, S. Sinsakul, and N. Panapitukkul, "Coastal erosion and mangrove progradation of Southern Thailand," Estuarine, Coastal and Shelf Science, vol. 68, no. 1, pp. 75-85, 2006.

[17] SEATEC, BEST, "Feasilibility study and preliminary design for alleviation of coastal erosion problem in the Upper Gulf of Thailand," Harbour Department of Thailand, 1994.

[18] C. E. Lovelock, I. C. Feller, M. C. Ball, B. M. J. Engelbrecht, and M. L. Ewe, "Differences in plant function in phosphorus- and nitrogen-limited mangrove ecosystems," New Phytologist, vol. 172, no. 3, pp. 514-522, 2006.

[19] APHA, AWWA, WPCF, Standard Method for the Examination of Water and Wastewater, American Public Health Association, Wash, USA, 17th edition, 1985.

[20] I. Solorzano, "Determination of ammonia in natural waters by the phenolhypochlorite method," Limnology and Oceanography, vol. 14, pp. 799-801, 1969.

[21] J. Murphy and J. P. Riley, "A modified single solution method for the determination of phosphate in natural waters," Analytica Chimica Acta, vol. 27, no. C, pp. 31-36, 1962.

[22] K. I. Aspila, H. Agemian, and A. S. Y. Chau, "A semi-automated method for the determination of inorganic, organic and total phosphate in sediments," The Analyst, vol. 101, no. 1200, pp. 187-197, 1976.

[23] J. I. Hedges and J. H. Stern, "Carbon and nitrogen determinations of carbonate-containing solids," Limnology \& Oceanography, vol. 29, no. 3, pp. 657-663, 1984.

[24] H. Tsutsumi and T. Kikuchi, "Benthic ecological of a small cove with seasonal oxygen depletion caused by organic pollution," Publications from the Amakusa Marine Biological Laboratory, vol. 7, pp. 17-40, 1983.

[25] F. F. Perez, F. G. Figueiras, and A. F. Rios, "Nutrient depletion and particulate matter near the ice-edge in the Weddell Sea," Marine Ecology Progress Series, vol. 112, no. 1-2, pp. 143-154, 1994.

[26] S. Tookwinas, The mitigation measures for the impacts of marine shrimp farming on coastal environment; A case study at Kung Krabaen Bay, Eastern Thailand, Doctoral thesis, Graduate School of Biosphere Sciences, Hiroshima University, Japan, 2001.

[27] B. V. Bhat and T. R. C. Gupta, "Macrobenthos of NethravatiGurupur Estuary, Mangalore," in Proceedings of the Symposium on Coastal Aquaculture, p. 1465, 1986.

[28] S. Angsupanich and R. Kuwabara, "Macrobenthic fauna in Thale Sap Songkla, a brackish lake in southern Thailand," Lakes and Reservoirs: Research and Management, vol. 1, no. 2, pp. 115-125, 1995. 
[29] M. Amino, "Macrobenthos and aquatic animals," in Report on the Effect of Waste Water Effluent from Sewage Disposal Plant in Takamatsu City to Fishing Grounds, pp. 59-86, 1979.

[30] R. Kuwabara, "Environment of sandy and muddy bottoms in shallow waters," Fisheries Engineering, vol. 21, pp. 53-60, 1985.

[31] Y. Yamaguchi, "Ecological characteristics and phytoplankton dynamics of lagoonal lake, Thale Sap Songkhla, Thailand," in The Coastal Environment and Ecosystem in Southeast Asia, Studies on the Lake Songhla Lagoon System, Thailand, pp. 4071, Faculty of Bio-industry, Tokyo University of Agriculture, Japan, 1995.

[32] I. C. Feller, D. F. Whigham, K. L. McKee, and C. E. Lovelock, "Nitrogen limitation of growth and nutrient dynamics in a disturbed mangrove forest, Indian River Lagoon, Florida," Oecologia, vol. 134, no. 3, pp. 405-414, 2003.

[33] Y. Mazda, M. Magi, M. Kogo, and Phan Nguyen Hong, "Mangroves as a coastal protection from waves in the Tong King Delta, Vietnam," Mangroves and Salt Marshes, vol. 1, no. 2, pp. 127-135, 1997.

[34] U. Thampanya, J. E. Vermaat, S. Sinsakul, and N. Panapitukkul, "Coastal erosion and mangrove progradation of Southern Thailand," Estuarine, Coastal and Shelf Science, vol. 68, no. 1, pp. 75-85, 2006.

[35] B. Kamali and R. Hashim, "Mangrove restoration without planting," Ecological Engineering, vol. 37, no. 2, pp. 387-391, 2011.

[36] M. Ebato, N. Matsui, M. Nomura, and K. Yonebayashi, "Estimation of buffering capacity of mangrove soils by using hydrophobic organic compoiunds, Atrazine and Linuraon," Soil Science and Plant Nutrition, vol. 50, no. 4, pp. 477-484, 2004. 

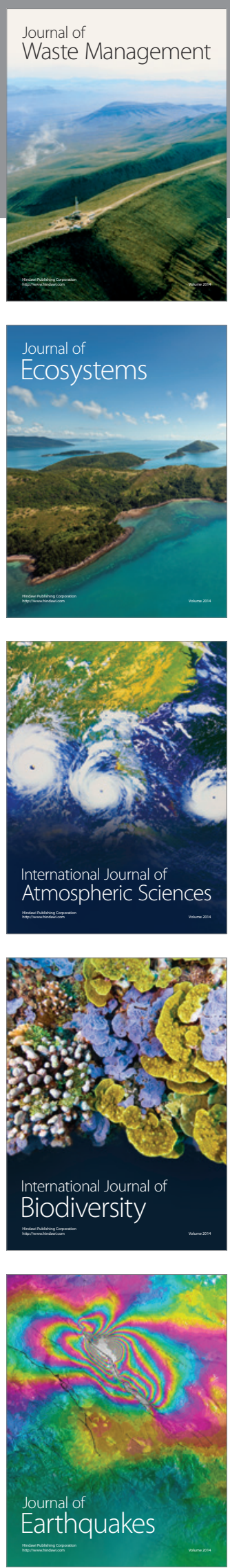
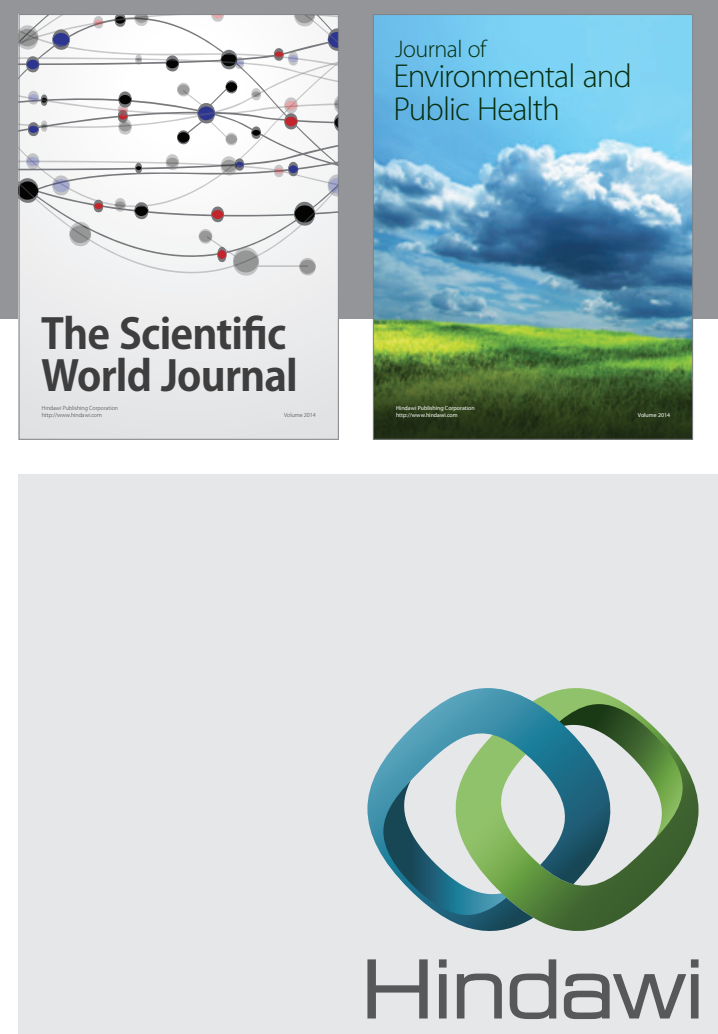

Submit your manuscripts at

http://www.hindawi.com
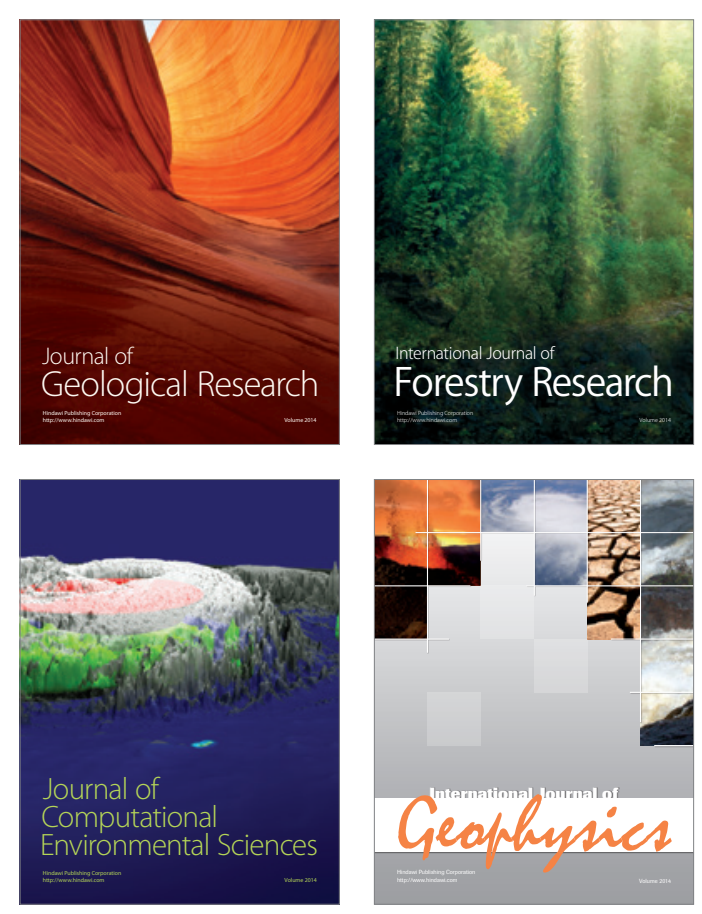
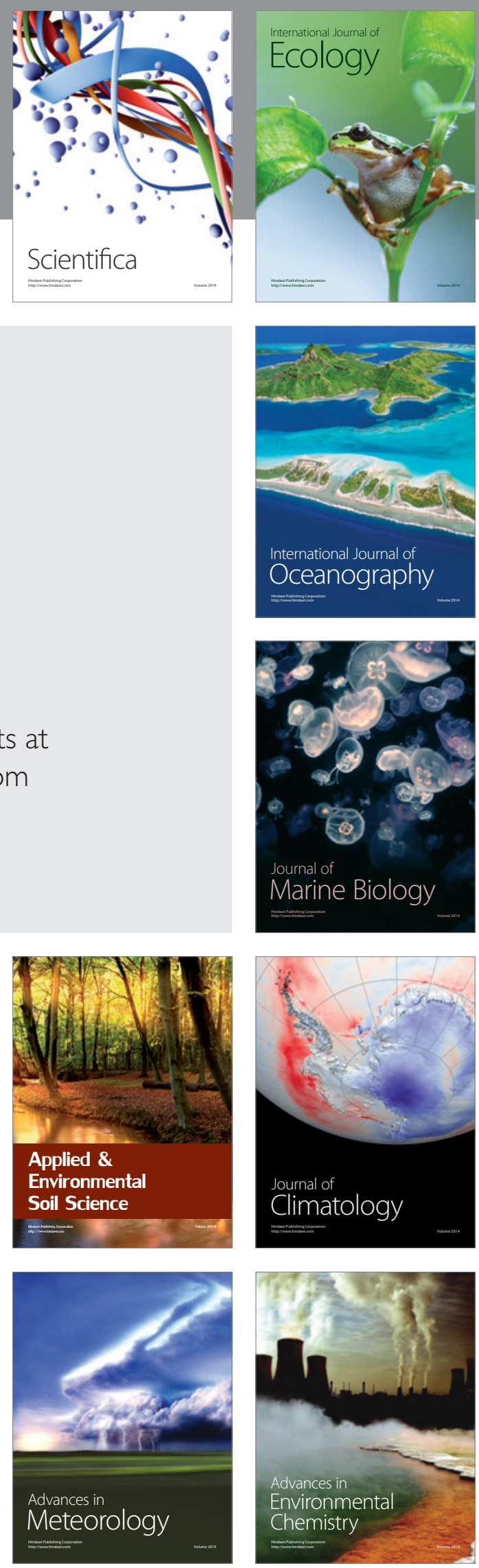